Article

\title{
Gold(I) Complexes with Ferrocenylphosphino Sulfonate Ligands: Synthesis and Application in the Catalytic Addition of Carboxylic Acids to Internal Alkynes in Water
}

\author{
Javier Francos ${ }^{1} \mathbb{C}$, María Esther Moreno-Narváez ${ }^{1}$, Victorio Cadierno ${ }^{1, *} \mathbb{\infty}$, Diego Sierra ${ }^{2, *}$, \\ Katherine Ariz ${ }^{2}$ and Johana Gómez ${ }^{3}$ \\ 1 Laboratorio de Compuestos Organometálicos y Catálisis (Unidad Asociada al CSIC), Centro de Innovación \\ en Química Avanzada (ORFEO-CINQA), Departamento de Química Orgánica e Inorgánica, IUQOEM, \\ Facultad de Química, Universidad de Oviedo, Julián Clavería 8, E-33006 Oviedo, Spain; \\ jfa1983@hotmail.com (J.F.); q.me.moreno@gmail.com (M.E.M.-N.) \\ 2 Laboratorio de Química Organometálica y Catálisis, Instituto de Química y Bioquímica, Facultad de Ciencias, \\ Universidad de Valparaíso, Av. Gran Bretaña 1111, Valparaíso 2340000, Chile; k.ariz.ledesma@gmail.com \\ 3 Núcleo Biotecnología Curauma, Pontificia Universidad Católica de Valparaíso, Av. Universidad 330, \\ Valparaíso 2340000, Chile; johanagomezuribe@gmail.com \\ * Correspondence: vcm@uniovi.es (V.C.); diego.sierra@uv.cl (D.S.); \\ Tel.: +34-985-103453 (V.C.); +56-322-508089 (D.S.)
}

Received: 28 October 2019; Accepted: 11 November 2019; Published: 14 November 2019

\begin{abstract}
The synthesis and characterization of novel gold(I) complexes containing hydrophilic ferrocenylphosphino sulfonate ligands, i.e., compounds $\left[\mathrm{AuCl}\left\{\left(\eta^{5}-\mathrm{C}_{5} \mathrm{H}_{3} \mathrm{PR}_{2}\left(\mathrm{SO}_{3}{ }^{\mathrm{i}} \mathrm{Pr}\right)\right) \mathrm{Fe}\left(\eta^{5}-\mathrm{C}_{5} \mathrm{H}_{5}\right)\right\}\right]$ $(\mathrm{R}=\mathrm{Ph}(\mathbf{2 a}), p$-Tol (2b), Cy (2c)), are presented, including a single-crystal X-ray diffraction study on 2a. Complexes $\mathbf{2 a - c}$ were checked as catalysts for the intermolecular addition of carboxylic acids to nonactivated internal alkynes using water as a green reaction medium. The best results in terms of activity were obtained with 2a in combination with AgOAc, which was able to promote the selective anti addition of a variety of aromatic, aliphatic, and $\alpha, \beta$-unsaturated carboxylic acids to both symmetrical and unsymmetrical internal alkynes at $60{ }^{\circ} \mathrm{C}$, employing metal loadings of only $2 \mathrm{~mol} \%$.
\end{abstract}

Keywords: ferrocenylphosphines; gold catalysts; aqueous catalysis; enol esters; hydrooxycarbonylation reactions

\section{Introduction}

Enol esters represent an important class of synthons in organic chemistry, commonly employed as intermediates, among others, in cross-coupling [1-3], asymmetric hydrogenation [4-6], and cyclization reactions [7-9], as well as monomers in polymerization and oligomerization processes [10-12]. Among the different methods of synthesis of these valuable molecules, the intermolecular addition of carboxylic acids to alkynes catalyzed by transition metals (hydro-oxycarbonylation reaction) is probably the most straightforward and atom-economical one because the starting materials are widely available and no byproducts are generated in the process. A large number of catalytic systems, mainly involving Groups 8-11 metals, have been reported in the literature, with those based on ruthenium being probably the most popular [13-17]. However, the vast majority of studies have focused on the hydro-oxycarbonylation of terminal alkynes. Examples of the intermolecular addition of carboxylic acids to internal alkynes still remain scarce [18], and in most of the cases, only activated substrates, such as trifluoromethylated alkynes [19], acetylenic esters [20], ynol ethers [21], ynamides [22], 
or iodoalkynes [23], have been considered. For nonactivated internal alkynes, only a very limited number of gold- and cobalt-based catalysts have proven effective under mild conditions (temperatures below $100{ }^{\circ} \mathrm{C}$ ) [24-27]. It is also worth noting that, despite the growing interest in developing catalytic transformations in environmentally friendly aqueous media [28], efforts devoted to finding catalytic systems able to promote the hydro-oxycarbonylation of alkynes in water have been very scarce, with most of the examples dealing with intramolecular processes [29]. In fact, the only protocol for the intermolecular addition of carboxylic acids to internal alkynes in water that can be currently found in the literature was developed by our group, making use of the gold(I) complex [AuCl$\left.\left(\mathrm{PPh}_{3}\right)\right]$ in combination with the chloride abstractor AgOAc [30]. As shown in Scheme 1, the trisubstituted enol ester products were generated with complete Z-stereoselectivity as the result of the anti-addition of the carboxylate anion to the corresponding cationic $\pi$-alkyne-Au(I) intermediate.

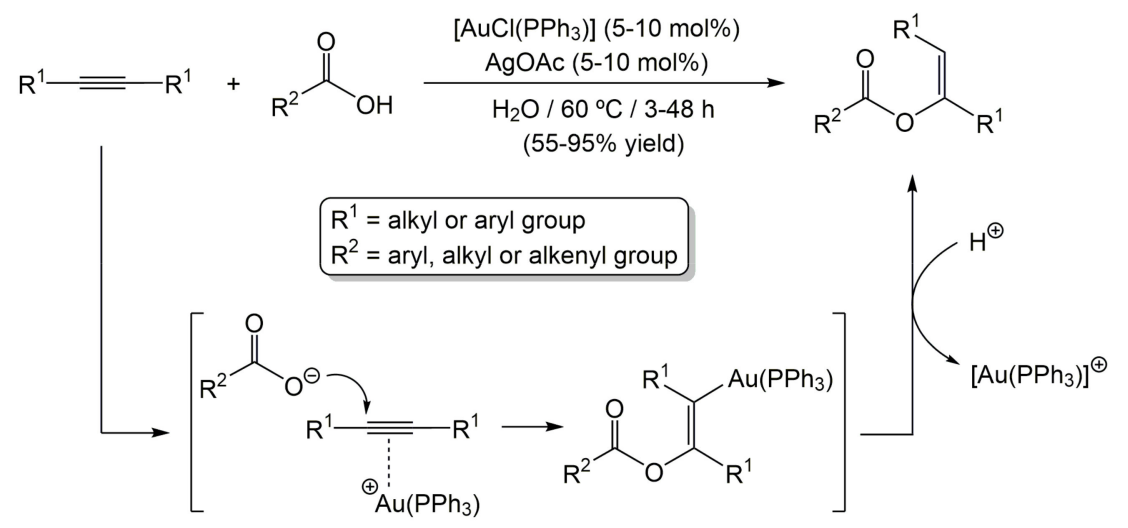

Scheme 1. Catalytic addition of carboxylic acids to internal alkynes in $\mathrm{H}_{2} \mathrm{O}$, employing [ $\left.\mathrm{AuCl}\left(\mathrm{PPh}_{3}\right)\right]$.

Given the tremendous effect that ligands can exert in homogeneous Au catalysis [31], we reasoned that a change in the nature of the coordinated phosphine ligand could improve these previous results. In particular, we turned our attention to the ferrocenylphosphino sulfonates $1 \mathrm{a}-\mathrm{c}$ recently synthesized by us (Scheme 2), because preliminary studies showed their utility as auxiliary $P$-donor ligands in ruthenium-catalyzed $\mathrm{C}-\mathrm{H}$ activation processes in aqueous media [32]. In addition, compounds 1a-c represent rare examples of hydrophilic ferrocenylphosphines, a particular class of ligands whose potential in aqueous catalysis remains almost unexplored. Thus, in this work, the preparation of gold(I) complexes containing the ferrocenylphosphines 1a-c is presented, as well as an evaluation of their catalytic activity in hydro-oxycarbonylation reactions of nonactivated internal alkynes in water.

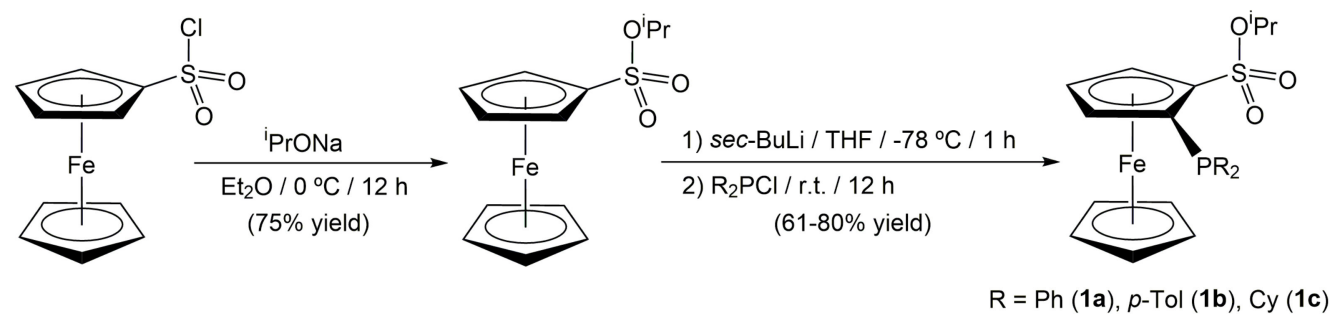

Scheme 2. Synthetic route employed for the preparation of the ferrocenyl sulfonate ligands 1a-c.

\section{Results and Discussion}

The treatment of dichloromethane solutions of the ferrocenylphosphino sulfonates $1 \mathbf{a}-\mathbf{c}$ with one equivalent of $\left[\mathrm{AuCl}\left(\mathrm{SMe}_{2}\right)\right]$ at room temperature led to the clean and fast formation of the novel gold(I)

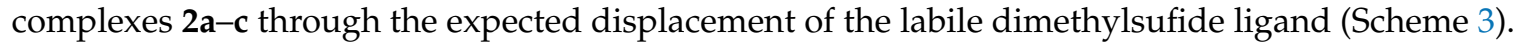




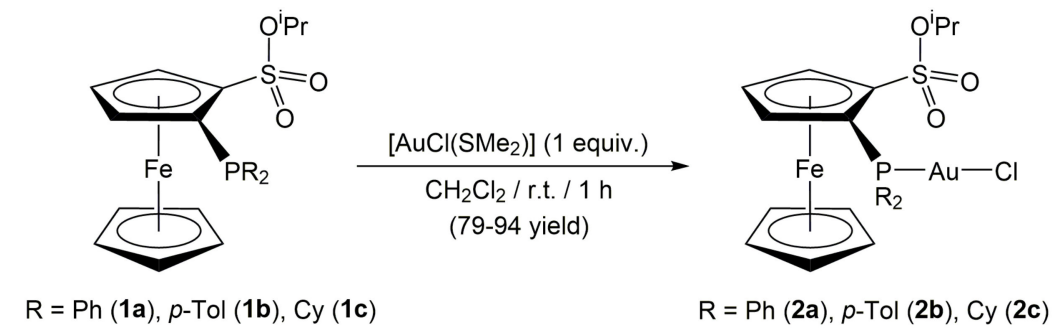

Scheme 3. Synthesis of the ferrocenylphosphino sulfonate-gold(I) complexes 2a-c.

The characterization of complexes $\mathbf{2 a - c}$, which were isolated as air-stable yellow solids in 79-94\% yield, was straightforward following their analytical and spectroscopic data (details are given in Materials and Methods). In particular, the ${ }^{31} \mathrm{P}\left\{{ }^{1} \mathrm{H}\right\}$ NMR spectra were very informative, showing in all the cases a singlet resonance at $\delta_{\mathrm{P}} 26.2-49.8 \mathrm{ppm}$, strongly deshielded with respect to that of the free ferrocenylphosphino sulfonates $1 \mathrm{a}-\mathrm{c}\left(\delta_{\mathrm{P}}\right.$ from -22.2 to $\left.-12.0 \mathrm{ppm}\right)$ [32]. The ${ }^{1} \mathrm{H}$ and ${ }^{13} \mathrm{C}\left\{{ }^{1} \mathrm{H}\right\}$ NMR spectra were also fully consistent with the proposed formulations, featuring two sets of signals for the R substituents of the phosphino groups, as well as for the diastereotopic methyl units of the $\mathrm{O}-{ }^{\mathrm{i}} \mathrm{Pr}$ moieties (i.e., two doublet signals at $\delta_{\mathrm{H}} 0.91-1.46 \mathrm{ppm}\left({ }^{3} \mathrm{~J}_{\mathrm{HH}}=6.0-6.3 \mathrm{~Hz}\right)$ and two singlets at $\delta_{\mathrm{C}} 22.6-23.6 \mathrm{ppm}$ ), as a consequence of the planar chirality of the ferrocenyl fragments due to the 1,2-disubstitution of one of their Cp rings. In addition, the structure of complex $2 a$ was unambiguously confirmed by means of a single-crystal X-ray diffraction study. X-ray quality crystals were obtained by slow diffusion of hexane into a saturated solution of $\mathbf{2 a}$ in dichloromethane. An ORTEP-type view of the molecule, along with selected structural parameters, is shown in Figure 1.

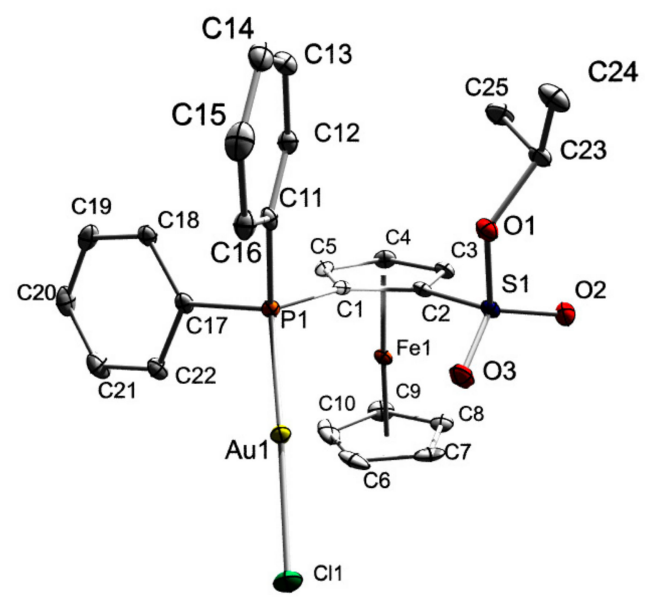

Figure 1. ORTEP-type view of the structure of complex 2a showing the crystallographic labelling scheme. Hydrogen atoms have been omitted for clarity. Thermal ellipsoids are drawn at the $30 \%$ probability level. Selected bond distances $(\AA)$ and angles (deg): $\operatorname{Fe}(1)-C^{*}=1.6300(5)$; $\mathrm{Fe}(1)-\mathrm{C}^{* *}=1.6545(5) ; \mathrm{Au}(1)-\mathrm{Cl}(1)=2.2893(9) ; \mathrm{Au}(1)-\mathrm{P}(1)=2.2340(9) ; \mathrm{P}(1)-\mathrm{C}(1)=1.805(4) ;$ $\mathrm{P}(1)-\mathrm{C}(11)=1.823(4) ; \mathrm{P}(1)-\mathrm{C}(17)=1.808(4) ; \mathrm{S}(1)-\mathrm{C}(2)=1.741(4) ; \mathrm{S}(1)-\mathrm{O}(1)=1.570(2) ; \mathrm{S}(1)-\mathrm{O}(2)=1.426(3)$; $\mathrm{S}(1)-\mathrm{O}(3)=1.429(3) ; \mathrm{O}(1)-\mathrm{C}(23)=1.486(4) ; \mathrm{C}^{*}-\mathrm{Fe}-\mathrm{C}^{* *}=175.67(4) ; \mathrm{P}(1)-\mathrm{Au}(1)-\mathrm{Cl}(1)=175.72(3)$; $\mathrm{Au}(1)-\mathrm{P}(1)-\mathrm{C}(1)=115.6(1) ; \quad \mathrm{Au}(1)-\mathrm{P}(1)-\mathrm{C}(11)=115.1(1) ; \quad \mathrm{Au}(1)-\mathrm{P}(1)-\mathrm{C}(11)=110.2(1) ;$ $\mathrm{C}(1)-\mathrm{P}(1)-\mathrm{C}(11)=105.5(2) ; \quad \mathrm{C}(1)-\mathrm{P}(1)-\mathrm{C}(17)=102.8(2) ; \quad \mathrm{C}(11)-\mathrm{P}(1)-\mathrm{C}(17) \quad=\quad 106.5(2) ;$ $\mathrm{C}(2)-\mathrm{S}(1)-\mathrm{O}(1)=103.4(2) ; \mathrm{C}(2)-\mathrm{S}(1)-\mathrm{O}(2)=108.3(2) ; \mathrm{C}(2)-\mathrm{S}(1)-\mathrm{O}(3)=109.3(2) ; \mathrm{O}(1)-\mathrm{S}(1)-\mathrm{O}(2)=110.8(2)$; $\mathrm{O}(1)-\mathrm{S}(1)-\mathrm{O}(3)=104.2(2) ; \mathrm{O}(2)-\mathrm{S}(1)-\mathrm{O}(3)=119.8(2) ; \mathrm{S}(1)-\mathrm{O}(1)-\mathrm{C}(23)=120.4(2) ; \mathrm{C}^{*}$ and $\mathrm{C}^{* *}$ denote the centroids of the cyclopentadienyl rings $(C(1), C(2), C(3), C(4)$, and $C(5)$, and $C(6), C(7), C(8), C(9)$, and $\mathrm{C}(10)$, respectively).

The coordination around the gold atom is almost linear with a $\mathrm{P}(1)-\mathrm{Au}(1)-\mathrm{Cl}(1)$ angle of $175.72(3)^{\circ}$, and bond distances $\mathrm{Au}(1)-\mathrm{P}(1)$ and $\mathrm{Au}(1)-\mathrm{Cl}(1)$ of 2.2340(9) and 
2.2893(9) $\AA$, respectively. These bonding parameters compare well with those previously found in the solid-state crystal structures of related ferrocenylphosphine-gold(I) complexes, like $\left[\mathrm{Au}_{2} \mathrm{Cl}_{2}\left(\mu\right.\right.$-dppf)] (dppf $=1,1^{\prime}$-bis(diphenylphosphino)ferrocene; $\mathrm{Au}-\mathrm{P}=2.2262(13) \AA$, $\mathrm{Au}-\mathrm{Cl}=2.2815(13) \AA$, and $\left.\mathrm{P}-\mathrm{Au}-\mathrm{Cl}=179.59(5)^{\circ}\right)$ [33], $\left[\mathrm{Au}_{2} \mathrm{Cl}_{2}\left\{\mu-\left(\eta^{5}-1,3-\mathrm{C}_{5} \mathrm{H}_{3} \mathrm{PPh}_{2}\left(\mathrm{OSi}^{\mathrm{i}} \mathrm{Pr}_{3}\right)\right)_{2} \mathrm{Fe}\right\}\right]$ $\left(\mathrm{Au}-\mathrm{P}=2.2282(9) \AA, \mathrm{Au}-\mathrm{Cl}=2.2814(10) \AA\right.$, and $\left.\mathrm{P}-\mathrm{Au}-\mathrm{Cl}=177.35(4)^{\circ}\right)$ [34] or $\left[\mathrm{AuCl}\left\{\left(\eta^{5}-1,2-\mathrm{C}_{5} \mathrm{H}_{3} \mathrm{PPh}_{2}(1-\right.\right.\right.$ naphthyl $\left.\left.\left.)\right) \mathrm{Fe}\left(\eta^{5}-\mathrm{C}_{5} \mathrm{H}_{5}\right)\right\}\right](\mathrm{Au}-\mathrm{P}=2.2278(11) \AA, \mathrm{Au}-\mathrm{Cl}=2.2845(11) \AA$, and $\mathrm{P}-\mathrm{Au}-\mathrm{Cl}=174.16(5)^{\circ}$ ) [35]. On the other hand, the observed bond distances within the ferrocenylphosphine sulfonate skeleton were very similar to those found in the structure of the free ligand 1a $( \pm 0.04 \AA)$ [32]. The same can be said about the bond angles, where the most noticeable differences were the increase in ca. $5-6^{\circ}$ of the $C(1)-P(1)-C(11)$ and $C(1)-P(1)-C(17)$ angles when passing from 1a to $\mathbf{2 a}$. All these observations indicate a negligible influence of the gold coordination on the geometry of the ligand.

With the complexes $\left[\mathrm{AuCl}\left\{\left(\eta^{5}-\mathrm{C}_{5} \mathrm{H}_{3} \mathrm{PR}_{2}\left(\mathrm{SO}_{3}{ }^{\mathrm{i}} \mathrm{Pr}\right)\right) \mathrm{Fe}\left(\eta^{5}-\mathrm{C}_{5} \mathrm{H}_{5}\right)\right\}\right](\mathbf{2 a}-\mathbf{c})$ in hand, we next explored their catalytic potential in hydro-oxycarbonylation reactions of internal alkynes in water. In particular, a first set of experiments was performed with complex $\mathbf{2 a}$ and the model substrates hex-3-yne (3a) and benzoic acid (4a) (see Table 1).

Table 1. Addition of benzoic acid (4a) to hex-3-yne (3a) catalyzed by complexes $2 a-c$ in water. ${ }^{1}$.

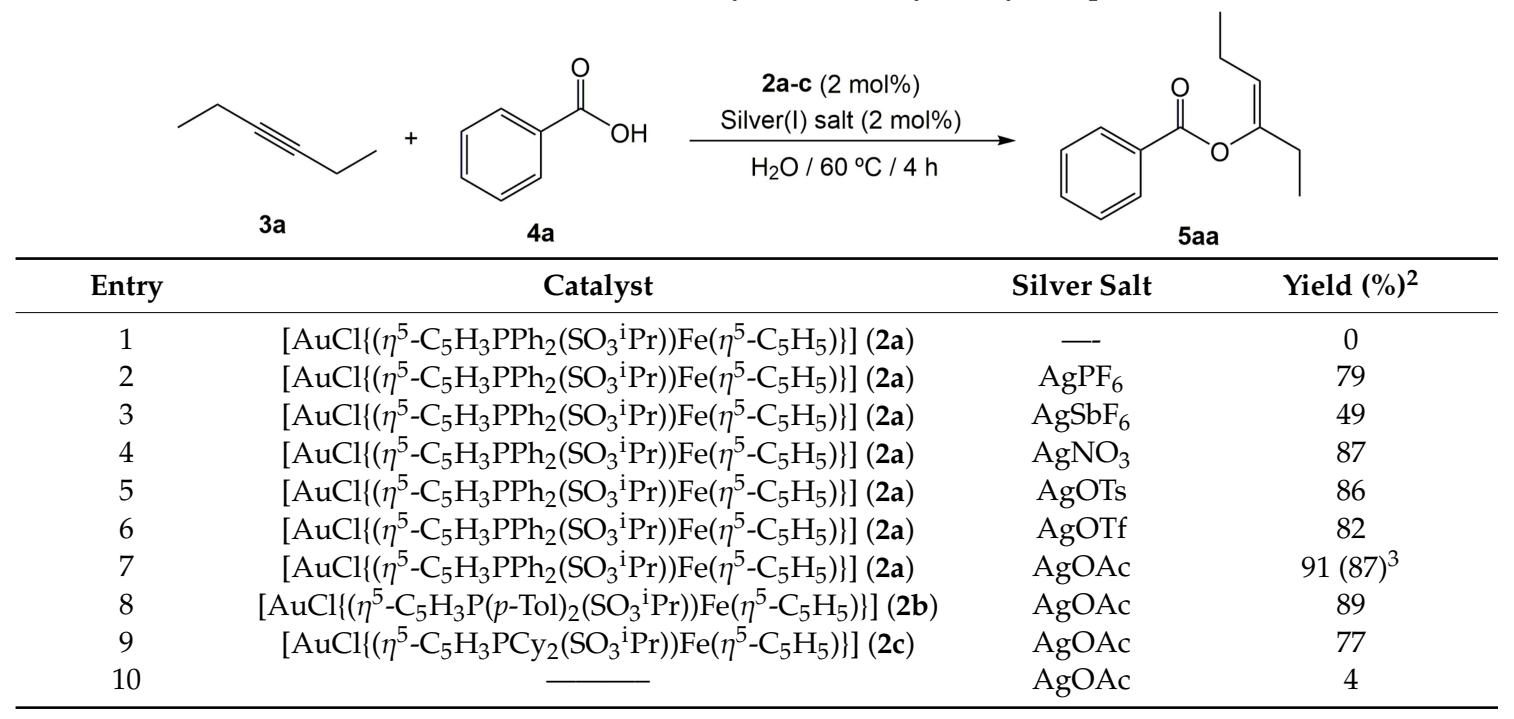

${ }^{1}$ All the reactions were performed under $\mathrm{Ar}$ atmosphere at $60^{\circ} \mathrm{C}$ using $1.2 \mathrm{mmol}$ of hex-3-yne (3a), $1.0 \mathrm{mmol}$ of benzoic acid (4a), and $3 \mathrm{~mL}$ of water. ${ }^{2}$ Yields of 5 aa determined by gas chromatography (GC). ${ }^{3}$ Isolated yield after work-up in brackets.

As shown in entry 1 , when a mixture of $\mathbf{3 a}(1.2 \mathrm{mmol}), \mathbf{4 a}(1 \mathrm{mmol})$, and complex $\mathbf{2 a}(0.02 \mathrm{mmol}$; $2 \mathrm{~mol} \%)$ in water $(3 \mathrm{~mL})$ was heated at $60{ }^{\circ} \mathrm{C}$ for $4 \mathrm{~h}$, no reaction was observed, suggesting the need for a halide extractor to generate the catalytically active cationic gold(I) species. In this regard, different silver(I) salts (2 mol\%) were screened (entries 2-7), obtaining positive results in all cases. In particular, the best result was achieved with AgOAc, which led to the desired enol ester 5aa in $91 \%$ gas chromatography (GC) yield after $4 \mathrm{~h}$ of heating (entry 7). Work-up of the reaction mixture allowed for isolation of pure 5aa in 87\% yield (see details in Materials and Methods). Employing the same reaction conditions, the catalytic performance of the bis( $p$-tolyl)phosphino complex $\mathbf{2} \mathbf{b}$ was found to be very similar to that shown by complex $2 \mathrm{a}$ (entries $8 \mathrm{vs}$. 7). The dicyclohexylphosphino complex $2 \mathrm{c}$ proved to also be active in the addition process, but its effectiveness was slightly lower in comparison to that of $\mathbf{2 a}$ and $\mathbf{2 b}$ (entry 9 vs. 7 and 8). Although steric effects cannot be discarded, the lower reactivity of $2 \mathrm{c}$ is most probably related to the higher electronic density of the metal center, which reduces the electrophilic character of the corresponding gold cation disfavoring the coordination of the alkyne substrate. Also of note is the fact that, as previously observed employing the catalytic 
system [AuCl( $\left.\left(\mathrm{PPh}_{3}\right)\right] / \mathrm{AgOAc}$ (see Scheme 1) [30], all the reactions collected in Table 1 proceeded cleanly without any side-reaction associated with the hydration of the $\mathrm{C} \equiv \mathrm{C}$ bond or oligomerization processes, and with an exquisite anti selectivity (only the $Z$ isomer of $\mathbf{5 a a}$ is formed). A blank experiment with $\mathrm{AgOAc}$ alone confirmed that gold is responsible for the catalytic activity observed (entry 10). We would also like to highlight in this point that the effectiveness shown by the $2 \mathrm{a} / \mathrm{AgOAc}$ system in this reaction compares favorably with that reported for $\left[\mathrm{AuCl}\left(\mathrm{PPh}_{3}\right)\right] / \mathrm{AgOAc}(5 \mathrm{~mol} \%$ of both reagents were needed to generate $5 \mathbf{a a}$ in a comparable yield under identical experimental conditions) [30], which could be explained in terms of the higher solubility in the water of complex $2 \mathbf{a}$ (ca. $10 \mathrm{mg} / \mathrm{mL}$ at 60 ${ }^{\circ} \mathrm{C}$ ). However, the different reactivities observed between complexes $\mathbf{2 a}, \mathbf{2} \mathbf{b}$, and $\mathbf{2 c}$ do not seem to be related to their water solubilities, since the most soluble one $2 \mathrm{c}\left(\mathrm{ca} .13 \mathrm{mg} / \mathrm{mL}\right.$ at $\left.60^{\circ} \mathrm{C}\right)$ is the least effective (the solubility of $\mathbf{2} \mathbf{b}$ is identical to that of $\mathbf{2 a}$ ).

The scope of $\mathrm{Au}(\mathrm{I})$ complex $2 \mathrm{a}$ was subsequently explored by varying firstly the carboxylic acid reagent. Thus, as shown in Scheme 4 , different benzoic acids $4 \mathbf{b}-\mathbf{f}$ could be successfully added to hex-3-yne (3a), regardless of the electronic nature and substitution pattern of the aryl ring. As for 5aa, the resulting enol esters $\mathbf{5} \mathbf{a b}$-af were exclusively obtained as the corresponding $Z$ isomers, as assessed by comparison of their NMR data with literature values [30]. The use of 4-hydroxybenzoic acid (4f) led to an interesting result because, in addition to the expected hydro-oxycarbonylation reaction, the hydroalkoxylation of 3a also occurred, leading to the previously unknown enol ester 5af (to obtain this compound in good yield, a $3 \mathrm{a} / \mathbf{4} \mathbf{f}$ ratio of 2.4:1 was employed). We would like to remark here that, although gold-catalyzed intermolecular hydroalkoxylation reactions of alkynes have been extensively studied [36], no previous examples in water can be found in the literature. As exemplified with compounds 5ag-an, the addition process could also be extended to benzylic, homobenzylic, aliphatic, and $\alpha, \beta$-unsaturated carboxylic acids, thus confirming the wide scope of $2 \mathbf{a}$ towards the carboxylate partner (Scheme 2). The enol esters $\mathbf{5} \mathbf{a b}$-an were isolated, after extraction of the reaction mixture with diethyl ether and subsequent chromatographic purification, in $61-92 \%$ yield (conversions $\geq 85 \%$ were in all cases observed by GC), with reaction times ranging from 5 to $24 \mathrm{~h}$.

Additional studies varying the nature of the alkyne were also performed. Thus, as observed for hex-3-yne (3a), the addition of benzoic acid to oct-4-yne (3b) and but-2-yne (3c) also proceeded cleanly under the standard conditions, leading to the corresponding enol esters $5 \mathbf{b a}$ and $5 \mathbf{c a}$, which were isolated in $82-92 \%$ yield (see Scheme 4 ). In contrast, a very poor result was obtained when diphenylacetylene (3d) was employed as substrate, the reaction leading to a maximum $20 \%$ GC yield of the desired enol ester product $5 \mathrm{da}$ after $24 \mathrm{~h}$ (Scheme 4). The higher steric constraints of this particular alkyne could be behind this negative result.

To complete the study, the catalytic addition of benzoic acid (4a) to a nonsymmetrically substituted alkyne, i.e., 1-phenyl-1-propyne (3e), was finally explored. As shown in Scheme 5, the reaction proceeded in high yield after $20 \mathrm{~h}$, but with a relatively low regioselectivity. Thus, a nonseparable mixture of the regioisomeric enol esters 5ea and 5ea' was formed in ca. 2.2:1 ratio. 


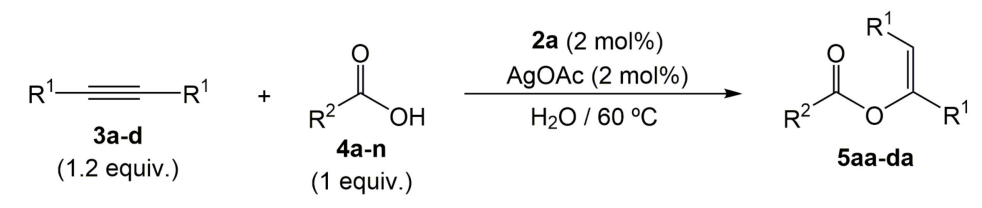<smiles>CC/C=C(/CC)OC(=O)c1ccccc1</smiles>

5aa $(87 \%, 4 \mathrm{~h})$<smiles>CC/C=C(/CC)OC(=O)c1c(F)c(F)c(F)c(F)c1F</smiles>

5ae $(89 \%, 6 \mathrm{~h})$<smiles>CC/C=C(/CC)OC(=O)NC</smiles>

$\mathrm{n}=5 ; \mathbf{5 a i}(92 \%, 6 \mathrm{~h})$ $\mathrm{n}=6 ; \mathbf{5}$ aj $(83 \%, 6 \mathrm{~h})$<smiles>CC/C=C(/CC)OC(=O)/C=C/c1ccccc1</smiles>

$\operatorname{5an}(79 \%, 8 \mathrm{~h})$<smiles>CC/C=C(/CC)OC(=O)c1cccc(C)c1</smiles>

$5 a b(86 \%, 8 \mathrm{~h})$<smiles>CC/C=C(/CC)OC(=O)c1ccc(O/C(=C\CC)CC)cc1</smiles>

(2.4 equiv. of $3 \mathbf{a}$ were employed)<smiles>CC/C=C(/CC)OC(=O)C1CCCCC1</smiles>

5ak $(80 \%, 6 \mathrm{~h})$<smiles>CCC/C=C(/CCC)OC(=O)c1ccccc1</smiles>

5 ba $(82 \%, 5 \mathrm{~h})$<smiles>CC/C=C(/CC)OC(=O)c1c(C)cc(C)cc1C</smiles>

5ac $(92 \%, 6$ h)<smiles>CC/C=C(/CC)OC(=O)Cc1ccccc1</smiles><smiles>CC/C=C(/CC)OC(=O)CCC1CCCC1</smiles>

5al $(91 \%, 6 \mathrm{~h})$<smiles>C/C=C(/C)OC(=O)c1ccccc1</smiles>

5ca $(92 \%, 24$ h)<smiles>CC/C=C(/CC)OC(=O)c1ccc([N+](=O)[O-])cc1</smiles>

5ad $(86 \%, 24 \mathrm{~h})$<smiles>CC/C=C(/C)OC(=O)CC(C)c1ccccc1</smiles><smiles>CC/C=C(/CC)OC(=O)C12CC3CC(CC(C3)C1)C2</smiles>

5am $(84 \%, 24 \mathrm{~h})$

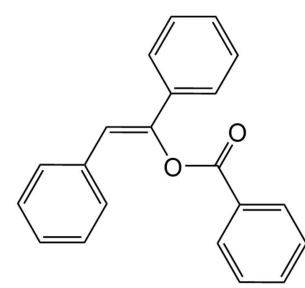

5da (20\% GC-yield, 24 h)

Scheme 4. Addition of different carboxylic acids to symmetrically substituted internal alkynes (isolated yields are given).<smiles>CC#Cc1ccccc1</smiles>

$3 e$

(1.2 equiv.)<smiles>O=C(O)c1ccccc1</smiles>

$4 a$

(1 equiv.)

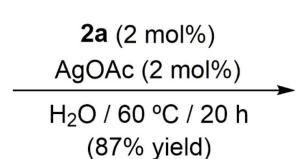

(87\% yield)

5 ea

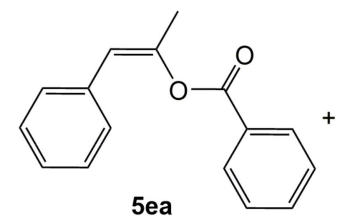

5 ea $/ 5 e^{\prime}$ ratio $=2.2: 1$<smiles>C=CC=C(C=C)C(=CC)OC(=O)c1ccccc1</smiles>

5ea'

Scheme 5. Addition of benzoic acid to 1-phenyl-1-propyne catalyzed by the gold(I) complex 2a.

\section{Materials and Methods}

All the synthetic procedures described in this article were performed under inert atmosphere (dry argon) using vacuum-line and Schlenk or sealed-tube techniques. Organic solvents were purified by standard methods and distilled under inert atmosphere before use [37]. All reagents employed in this work were obtained from commercial suppliers and used as received, with the exception of the ferrocenylphosphino sulfonate ligands $\left(\eta^{5}-\mathrm{C}_{5} \mathrm{H}_{3} \mathrm{PR}_{2}\left(\mathrm{SO}_{3}{ }^{\mathrm{i}} \mathrm{Pr}\right)\right) \mathrm{Fe}\left(\eta^{5}-\mathrm{C}_{5} \mathrm{H}_{5}\right)(\mathbf{1 a}-\mathbf{c})$ [32] and the gold(I) complex [AuCl(SMe $\left.\mathrm{SM}_{2}\right]$ [38], which were synthesized as previously described in the literature. NMR spectra were recorded at room temperature making use of Bruker DPX-300 or AV400 instruments 
(Billerica, MA, USA). The residual signal of the deuterated solvent was employed as reference for ${ }^{13} \mathrm{C}\left\{{ }^{1} \mathrm{H}\right\}$ and ${ }^{1} \mathrm{H}$ NMR chemical shifts, while $85 \% \mathrm{H}_{3} \mathrm{PO}_{4}$ was used as an external standard for the ${ }^{31} \mathrm{P}\left\{{ }^{1} \mathrm{H}\right\}$ NMR measurements. DEPT experiments were systematically performed for all the compounds synthesized. A PerkinElmer 1720-XFT spectrometer (Waltham, MA, USA) and a Hewlett Packard HP6890 apparatus (Supelco Beta-Dex ${ }^{\mathrm{TM}} 120$ column, 30 m length, $250 \mu \mathrm{m}$ diameter, (Palo Alto, CA, USA) were employed for IR and GC measurements, respectively. Elemental analyses and HRMS data (QTOF Bruker Impact II mass spectrometer) were provided by the Analytical Service of the Instituto de Investigaciones Químicas (IIQ-CSIC) of Seville and the General Services of the University of Oviedo, respectively. Merck silica gel 60 (230-400 mesh) was employed for the chromatographic work-ups.

3.1. General Procedure for the Preparation of Complexes $\left.\left[\mathrm{AuCl}\left(\eta^{5}-\mathrm{C}_{5} \mathrm{H}_{3} \mathrm{PR}_{2}\left(\mathrm{SO}_{3}{ }^{i} \mathrm{Pr}\right)\right) \mathrm{Fe}\left(\eta^{5}-\mathrm{C}_{5} \mathrm{H}_{5}\right)\right\}\right](\mathrm{R}=\mathrm{Ph}$ $(2 a), p-\operatorname{Tol}(2 b), C y(2 c))$

In a Schlenk flask filled with Ar and equipped with a stir bar, the corresponding ferrocenylphosphino sulfonate ligand $\mathbf{1 a}-\mathbf{c}(0.40 \mathrm{mmol})$ was dissolved in $10 \mathrm{~mL}$ of dichloromethane. Then, $0.40 \mathrm{mmol}(0.119 \mathrm{~g})$ of $\left[\mathrm{AuCl}\left(\mathrm{SMe}_{2}\right)\right]$ was added to the resulting solution, and the mixture was stirred at room temperature for $1 \mathrm{~h}$ (a color change from orange-red to yellow was observed). After this time, the solvent was removed under vacuum, and the yellow solid obtained recrystallized from a $1: 1 \mathrm{v} / \mathrm{v}$ dichloromethane/hexane mixture (ca. $20 \mathrm{~mL}$ ), washed with hexane (ca. $10 \mathrm{~mL}$ ), and dried in vacuo. Characterization data for the resulting $\mathrm{Au}(\mathrm{I})$ complexes $\mathbf{2 a}-\mathbf{c}$ are as follows:

\subsection{1. $\left[\mathrm{AuCl}\left\{\left(\eta^{5}-\mathrm{C}_{5} \mathrm{H}_{3} \mathrm{PPh}_{2}\left(\mathrm{SO}_{3}{ }^{\mathrm{i}} \mathrm{Pr}\right)\right) \mathrm{Fe}\left(\eta^{5}-\mathrm{C}_{5} \mathrm{H}_{5}\right)\right\}\right](2 \mathrm{a})$}

Yield: $0.235 \mathrm{~g}(81 \%) .{ }^{31} \mathrm{P}\left\{{ }^{1} \mathrm{H}\right\} \mathrm{NMR}\left(121 \mathrm{MHz}, \mathrm{CDCl}_{3}\right): \delta=27.7$ (s) ppm. ${ }^{1} \mathrm{H}$ NMR $(300 \mathrm{MHz}$, $\left.\mathrm{CDCl}_{3}\right): \delta=7.76-7.69(\mathrm{~m}, 2 \mathrm{H}, \mathrm{Ph}), 7.58-7.45(\mathrm{~m}, 8 \mathrm{H}, \mathrm{Ph}), 5.17$ and $3.87\left(\mathrm{~s}, 1 \mathrm{H}\right.$ each, $\mathrm{CH}$ of $\left.\mathrm{C}_{5} \mathrm{H}_{3}\right), 4.73$ (sept, $\left.1 \mathrm{H},{ }^{3} J_{\mathrm{HH}}=6.3 \mathrm{~Hz}, \mathrm{CHMe}\right), 4.63\left(\mathrm{~s}, 6 \mathrm{H}, \mathrm{C}_{5} \mathrm{H}_{5}\right.$ and $\mathrm{CH}$ of $\left.\mathrm{C}_{5} \mathrm{H}_{3}\right), 1.14$ and $0.91(\mathrm{~d}, 3 \mathrm{H}$ each, $\left.{ }^{3} J_{\mathrm{HH}}=6.3 \mathrm{~Hz}, \mathrm{CHMe} 2\right) \mathrm{ppm} .{ }^{13} \mathrm{C}\left\{{ }^{1} \mathrm{H}\right\} \mathrm{NMR}\left(100 \mathrm{MHz}, \mathrm{CDCl}_{3}\right): \delta=134.6$ and $133.9\left(\mathrm{~d}, J_{\mathrm{PC}}=14.7 \mathrm{~Hz}\right.$, $\mathrm{CH}_{\text {ortho }}$ or $\mathrm{CH}_{\text {meta }}$ of Ph), 132.1 and $131.8\left(\mathrm{~d}, J_{\mathrm{PC}}=2.2 \mathrm{~Hz}, \mathrm{CH}_{\text {para }}\right.$ of $\left.\mathrm{Ph}\right), 129.7\left(\mathrm{~d}, \mathrm{~J}_{\mathrm{PC}}=61.1 \mathrm{~Hz}, \mathrm{C}_{\text {ipso }}\right.$ of Ph), $129.5\left(\mathrm{~d}, J_{\mathrm{PC}}=62.0 \mathrm{~Hz}, \mathrm{C}_{\text {ipso }}\right.$ of $\left.\mathrm{Ph}\right), 129.0\left(\mathrm{~d}, J_{\mathrm{PC}}=12.0 \mathrm{~Hz}, \mathrm{CH}_{\text {ortho }}\right.$ or $\mathrm{CH}_{\text {meta }}$ of Ph), 128.8 $\left(\mathrm{d}, J_{\mathrm{PC}}=12.2 \mathrm{~Hz}, \mathrm{CH}_{\text {ortho }}\right.$ or $\mathrm{CH}_{\text {meta }}$ of $\left.\mathrm{Ph}\right), 88.9\left(\mathrm{~d}, J_{\mathrm{PC}}=12.0 \mathrm{~Hz}, \mathrm{C}_{\text {of }} \mathrm{C}_{5} \mathrm{H}_{3}\right), 77.3\left(\mathrm{~d}, J_{\mathrm{PC}}=5.7 \mathrm{~Hz}\right.$, $\mathrm{CH}$ of $\left.\mathrm{C}_{5} \mathrm{H}_{3}\right), 76.5\left(\mathrm{~s}, \mathrm{CHMe}_{2}\right), 75.9\left(\mathrm{~d}, J_{\mathrm{PC}}=4.6 \mathrm{~Hz}, \mathrm{CH}\right.$ of $\left.\mathrm{C}_{5} \mathrm{H}_{3}\right), 73.5\left(\mathrm{~s}, \mathrm{C}_{5} \mathrm{H}_{5}\right), 72.0\left(\mathrm{~d}, J_{\mathrm{PC}}=6.9 \mathrm{~Hz}\right.$, $\mathrm{CH}$ of $\left.\mathrm{C}_{5} \mathrm{H}_{3}\right), 71.2\left(\mathrm{~d}, \mathrm{JPC}_{\mathrm{PC}}=66.2 \mathrm{~Hz}, \mathrm{C}\right.$ of $\left.\mathrm{C}_{5} \mathrm{H}_{3}\right), 23.0$ and $22.7\left(\mathrm{~s}, \mathrm{CHMe} e_{2}\right) \mathrm{ppm}$. IR $(\mathrm{KBr}): v=3107$ (w), $2981(\mathrm{w}), 2933(\mathrm{w}), 1436(\mathrm{~m}), 1330(\mathrm{~s}), 1207(\mathrm{~m}), 1166(\mathrm{~s}), 1151(\mathrm{~m}), 1096(\mathrm{~m}), 1037(\mathrm{w}), 961(\mathrm{w}), 901$ $(\mathrm{m}), 868(\mathrm{~s}), 838(\mathrm{~m}), 750(\mathrm{~m}), 693(\mathrm{~m}), 659(\mathrm{~s}), 599(\mathrm{~m}), 481(\mathrm{~m}) \mathrm{cm}^{-1}$. Elemental analysis calcd. (\%) for $\mathrm{C}_{25} \mathrm{H}_{25} \mathrm{O}_{3} \mathrm{AuClFePS}$ : C 41.43, H 3.48; found: C 41.47, H 3.47.

\subsection{2. $\left[\mathrm{AuCl}\left\{\left(\eta^{5}-\mathrm{C}_{5} \mathrm{H}_{3} \mathrm{P}(p-\mathrm{Tol})_{2}\left(\mathrm{SO}_{3}{ }^{\mathrm{i}} \mathrm{Pr}\right)\right) \mathrm{Fe}\left(\eta^{5}-\mathrm{C}_{5} \mathrm{H}_{5}\right)\right\}\right](2 \mathrm{~b})$}

Yield: $0.238 \mathrm{~g}(79 \%) .{ }^{31} \mathrm{P}\left\{{ }^{1} \mathrm{H}\right\} \mathrm{NMR}\left(121 \mathrm{MHz}, \mathrm{CDCl}_{3}\right): \delta=26.2$ (s) ppm. ${ }^{1} \mathrm{H} \mathrm{NMR}\left(300 \mathrm{MHz}, \mathrm{CDCl}_{3}\right)$ : $\delta=7.64-7.57\left(\mathrm{~m}, 2 \mathrm{H}, \mathrm{C}_{6} \mathrm{H}_{4} \mathrm{Me}\right), 7.45-7.38\left(\mathrm{~m}, 2 \mathrm{H}, \mathrm{C}_{6} \mathrm{H}_{4} \mathrm{Me}\right), 7.31-7.22\left(\mathrm{~m}, 4 \mathrm{H}, \mathrm{C}_{6} \mathrm{H}_{4} \mathrm{Me}\right), 5.15$ and $3.88(\mathrm{~s}$, $1 \mathrm{H}$ each, $\mathrm{CH}$ of $\left.\mathrm{C}_{5} \mathrm{H}_{3}\right), 4.71$ (sept, $1 \mathrm{H},{ }^{3} J_{\mathrm{HH}}=6.0 \mathrm{~Hz}, \mathrm{CHMe}$ ), $4.62\left(\mathrm{~s}, 6 \mathrm{H}, \mathrm{C}_{5} \mathrm{H}_{5}\right.$ and $\mathrm{CH}$ of $\left.\mathrm{C}_{5} \mathrm{H}_{3}\right), 2.44$ and $2.40\left(\mathrm{~s}, 3 \mathrm{H}\right.$ each, $\left.\mathrm{C}_{6} \mathrm{H}_{4} M e\right), 1.15$ and $0.93\left(\mathrm{~d}, 3 \mathrm{H}\right.$ each, $\left.{ }^{3} \mathrm{~J}_{\mathrm{HH}}=6.0 \mathrm{~Hz}, \mathrm{CHMe} 2\right) \mathrm{ppm} .{ }^{13} \mathrm{C}\left\{{ }^{1} \mathrm{H}\right\} \mathrm{NMR}$ $\left(100 \mathrm{MHz}, \mathrm{CDCl}_{3}\right): \delta=142.6$ and $142.3\left(\mathrm{~s}, \mathrm{C}_{\text {para }}\right.$ of $\left.\mathrm{C}_{6} \mathrm{H}_{4} \mathrm{Me}\right), 134.5$ and $133.9\left(\mathrm{~d}, J_{\mathrm{PC}}=15.1 \mathrm{~Hz}, \mathrm{CH}_{\text {ortho }}\right.$ or $\mathrm{CH}_{\text {meta }}$ of $\left.\mathrm{C}_{6} \mathrm{H}_{4} \mathrm{Me}\right), 129.7$ and $129.5\left(\mathrm{~d}, J_{\mathrm{PC}}=12.3 \mathrm{~Hz}, \mathrm{CH}_{\text {ortho }}\right.$ or $\mathrm{CH}_{\text {meta }}$ of $\left.\mathrm{C}_{6} \mathrm{H}_{4} \mathrm{Me}\right), 126.5$ and 126.3 $\left(\mathrm{d}, J_{\mathrm{PC}}=63.8 \mathrm{~Hz}, \mathrm{C}_{\mathrm{ipso}}\right.$ of $\left.\mathrm{C}_{6} \mathrm{H}_{4} \mathrm{Me}\right), 88.7\left(\mathrm{~d}, J_{\mathrm{PC}}=1.9 \mathrm{~Hz}, \mathrm{C}_{\text {of }} \mathrm{C}_{5} \mathrm{H}_{3}\right), 77.3\left(\mathrm{~d}, J_{\mathrm{PC}}=6.0 \mathrm{~Hz}, \mathrm{CH}\right.$ of $\left.\mathrm{C}_{5} \mathrm{H}_{3}\right)$, $76.5\left(\mathrm{~s}, \mathrm{CHMe}_{2}\right), 75.8\left(\mathrm{~d}, J_{\mathrm{PC}}=4.5 \mathrm{~Hz}, \mathrm{CH}\right.$ of $\left.\mathrm{C}_{5} \mathrm{H}_{3}\right), 73.4\left(\mathrm{~s}, \mathrm{C}_{5} \mathrm{H}_{5}\right), 71.7\left(\mathrm{~d}, J_{\mathrm{PC}}=6.9 \mathrm{~Hz}, \mathrm{CH}\right.$ of $\left.\mathrm{C}_{5} \mathrm{H}_{3}\right), 72.0$ $\left(\mathrm{d}, J_{\mathrm{PC}}=65.9 \mathrm{~Hz}, \mathrm{C}\right.$ of $\left.\mathrm{C}_{5} \mathrm{H}_{3}\right), 23.0$ and $22.6(\mathrm{~s}, \mathrm{CHMe}), 21.5$ and $21.4\left(\mathrm{~s}, \mathrm{C}_{6} \mathrm{H}_{4} \mathrm{Me}\right) \mathrm{ppm}$. IR $(\mathrm{KBr}): v=2978$ (w), $2924(\mathrm{w}), 1597(\mathrm{w}), 1497(\mathrm{w}), 1368(\mathrm{~m}), 1357(\mathrm{~m}), 1331(\mathrm{~m}), 1202(\mathrm{~m}), 1166(\mathrm{~s}), 1100(\mathrm{~s}), 1035(\mathrm{w}), 960$ $(\mathrm{w}), 916(\mathrm{~s}), 881(\mathrm{~m}), 833(\mathrm{w}), 806(\mathrm{~m}), 754(\mathrm{w}), 627(\mathrm{~m}), 507(\mathrm{~m}), 495(\mathrm{~m}) \mathrm{cm}^{-1}$. Elemental analysis calcd. (\%) for $\mathrm{C}_{27} \mathrm{H}_{29} \mathrm{O}_{3} \mathrm{AuClFePS}$ : C 43.08, H 3.88; found: C 43.15, H 3.84 . 


\subsection{3. $\left[\mathrm{AuCl}\left\{\left(\eta^{5}-\mathrm{C}_{5} \mathrm{H}_{3} \mathrm{PCy}\left(\mathrm{SO}_{3}{ }^{\mathrm{i}} \mathrm{Pr}\right)\right) \mathrm{Fe}\left(\eta^{5}-\mathrm{C}_{5} \mathrm{H}_{5}\right)\right\}\right](2 \mathrm{c})$}

Yield: $0.277 \mathrm{~g}(94 \%) .{ }^{31} \mathrm{P}\left\{{ }^{1} \mathrm{H}\right\} \mathrm{NMR}\left(121 \mathrm{MHz}, \mathrm{CDCl}_{3}\right): \delta=49.8$ (s) ppm. ${ }^{1} \mathrm{H}$ NMR $(300 \mathrm{MHz}$, $\left.\mathrm{CDCl}_{3}\right): \delta=5.09,4.90$ and $4.76\left(\mathrm{~s}, 1 \mathrm{H}\right.$ each, $\mathrm{CH}$ of $\left.\mathrm{C}_{5} \mathrm{H}_{3}\right), 5.02\left(\mathrm{sept}, 1 \mathrm{H},{ }^{3} \mathrm{~J}_{\mathrm{HH}}=6.0 \mathrm{~Hz}, \mathrm{CHMe}_{2}\right), 4.57$ (s, $\left.5 \mathrm{H}, \mathrm{C}_{5} \mathrm{H}_{5}\right), 2.91-2.78$ and 2.61-2.55 (m, $1 \mathrm{H}$ each, $\mathrm{CH}$ of $\left.\mathrm{Cy}\right), 2.07,1.65\left(\mathrm{~m}, 12 \mathrm{H}, \mathrm{CH}_{2}\right.$ of $\left.\mathrm{Cy}\right), 1.48-1.12$ $\left(\mathrm{m}, 8 \mathrm{H}, \mathrm{CH}_{2}\right.$ of $\left.\mathrm{Cy}\right), 1.46$ and $1.32\left(\mathrm{~d}, 3 \mathrm{H}\right.$ each, $\left.{ }^{3} J_{\mathrm{HH}}=6.0 \mathrm{~Hz}, \mathrm{CHMe}\right) \mathrm{ppm} .{ }^{13} \mathrm{C}\left\{{ }^{1} \mathrm{H}\right\} \mathrm{NMR}(100 \mathrm{MHz}$, $\left.\mathrm{CDCl}_{3}\right): \delta=87.0\left(\mathrm{~d}, J_{\mathrm{PC}}=3.1 \mathrm{~Hz}, \mathrm{C}\right.$ of $\left.\mathrm{C}_{5} \mathrm{H}_{3}\right), 81.5\left(\mathrm{~d}, J_{\mathrm{PC}}=17.6 \mathrm{~Hz}, \mathrm{CH}\right.$ of $\left.\mathrm{C}_{5} \mathrm{H}_{3}\right), 77.2\left(\mathrm{~s}, \mathrm{CHMe}_{2}\right), 75.3$ $\left(\mathrm{d}, J_{\mathrm{PC}}=3.0 \mathrm{~Hz}, \mathrm{CH}\right.$ of $\left.\mathrm{C}_{5} \mathrm{H}_{3}\right), 73.2\left(\mathrm{~s}, \mathrm{C}_{5} \mathrm{H}_{5}\right), 72.1\left(\mathrm{~d}, J_{\mathrm{PC}}=9.5 \mathrm{~Hz}, \mathrm{CH}\right.$ of $\left.\mathrm{C}_{5} \mathrm{H}_{3}\right), 69.4\left(\mathrm{~d}, J_{\mathrm{PC}}=49.8 \mathrm{~Hz}\right.$, $\mathrm{C}$ of $\left.\mathrm{C}_{5} \mathrm{H}_{3}\right), 35.7\left(\mathrm{~d}, J_{\mathrm{PC}}=33.2 \mathrm{~Hz}, \mathrm{CH}\right.$ of $\left.\mathrm{Cy}\right), 35.2\left(\mathrm{~d}, J_{\mathrm{PC}}=33.9 \mathrm{~Hz}, \mathrm{CH}\right.$ of Cy), $33.5\left(\mathrm{~d}, J_{\mathrm{PC}}=3.9 \mathrm{~Hz}\right.$, $\mathrm{CH}_{2}$ of $\left.\mathrm{Cy}\right), 31.4\left(\mathrm{~d}, J_{\mathrm{PC}}=2.6 \mathrm{~Hz}, \mathrm{CH}_{2}\right.$ of $\left.\mathrm{Cy}\right), 29.2,28.6,25.7$ and $25.6\left(\mathrm{~s}, \mathrm{CH}_{2}\right.$ of $\left.\mathrm{Cy}\right), 26.7\left(\mathrm{~d}, J_{\mathrm{PC}}=13.6\right.$ $\mathrm{Hz}, \mathrm{CH}_{2}$ of $\left.\mathrm{Cy}\right), 26.6\left(\mathrm{~d}, 2 \mathrm{C}, \mathrm{J}_{\mathrm{PC}}=6.9 \mathrm{~Hz}, \mathrm{CH}_{2}\right.$ of $\left.\mathrm{Cy}\right), 26.5\left(\mathrm{~d}, \mathrm{~J}_{\mathrm{PC}}=13.2 \mathrm{~Hz}, \mathrm{CH}_{2}\right.$ of $\left.\mathrm{Cy}\right), 23.6$ and 22.9 (s, CHMe $)$ ppm. IR (KBr): v = 2928 (s), $2852(\mathrm{~m}), 1449(\mathrm{w}), 1369$ (s), $1334(\mathrm{~m}), 1204(\mathrm{~m}), 1167$ (s), 1093 $(\mathrm{w}), 1047(\mathrm{w}), 1003(\mathrm{w}), 905(\mathrm{~s}), 876(\mathrm{~s}), 837(\mathrm{~m}), 756(\mathrm{~m}), 628(\mathrm{~s}), 508(\mathrm{~m}), 483(\mathrm{w}) \mathrm{cm}^{-1}$. Elemental analysis calcd. (\%) for $\mathrm{C}_{25} \mathrm{H}_{37} \mathrm{O}_{3} \mathrm{AuClFePS}$ : C 40.75, $\mathrm{H} 5.06$; found: $\mathrm{C} 40.80, \mathrm{H} 5.10$.

\subsection{General Procedure for the Addition of Carboxylic Acids to Internal Alkynes Catalyzed by Complex $2 a$}

Under an argon atmosphere, the corresponding internal alkyne $3 \mathbf{a}-\mathbf{e}(1.2 \mathrm{mmol})$ and carboxylic acid $4 \mathbf{a}-\mathbf{n}(1 \mathrm{mmol})$, the gold complex $\left[\mathrm{AuCl}\left\{\left(\eta^{5}-\mathrm{C}_{5} \mathrm{H}_{3} \mathrm{PPh}_{2}\left(\mathrm{SO}_{3}{ }^{\mathrm{i}} \mathrm{Pr}\right)\right) \mathrm{Fe}\left(\eta^{5}-\mathrm{C}_{5} \mathrm{H}_{5}\right)\right\}\right](2 \mathbf{a})(0.014 \mathrm{~g}$; $0.02 \mathrm{mmol}), \mathrm{AgOAc}(0.003 \mathrm{~g} ; 0.02 \mathrm{mmol})$, and water $(3.0 \mathrm{~mL})$ were introduced into a Teflon-capped sealed tube, and the reaction mixture was stirred at $60^{\circ} \mathrm{C}$ for the indicated time (see Schemes 4 and 5). The course of the reaction was monitored regularly, taking samples of ca. $5 \mu \mathrm{L}$, which, after extraction with $\mathrm{CH}_{2} \mathrm{Cl}_{2}$, were analyzed by GC. Once the reaction finished, the mixture was extracted with diethyl ether $(3 \times 5 \mathrm{~mL})$, and the organic phase was dried over $\mathrm{MgSO}_{4}$ and evaporated to dryness. The resulting oily residue was purified by flash column chromatography over silica gel using diethyl ether/hexane (1:10) as eluent. The identity of the enol ester products was assessed by comparison of their NMR spectroscopic data with those previously reported by us [30] or, in the case of $\mathbf{5 a g}$, by Tsukada and coworkers [39]. Copies of the NMR spectra are included in the Supplementary Materials.

\subsection{Synthesis and Characterization of (Z)-Hex-3-en-3-yl 4-(((Z)-Hex-3-en-3-yl)oxy)benzoate 5af}

The novel enol ester 5af, isolated as a colourless oil after $24 \mathrm{~h}$ of heating, was obtained following the general procedure detailed in Section 3.2, starting from hex-3-yne (3a; $0.273 \mathrm{~mL} ; 2.4 \mathrm{mmol})$ and 4-hydroxybenzoic acid (4f; $0.138 \mathrm{~g} ; 1 \mathrm{mmol}$ ). Yield: $0.184 \mathrm{~g}(61 \%) .{ }^{1} \mathrm{H}$ NMR (300 $\left.\mathrm{MHz}, \mathrm{CDCl}_{3}\right)$ : $\delta=8.09-8.06\left(\mathrm{~m}, 2 \mathrm{H}, \mathrm{CH}_{\text {arom }}\right), 7.00-6.98\left(\mathrm{~m}, 2 \mathrm{H}, \mathrm{CH}_{\text {arom }}\right), 5.11(\mathrm{~m}, 2 \mathrm{H},=\mathrm{CH}), 2.33-2.28\left(\mathrm{~m}, 2 \mathrm{H}, \mathrm{CH}_{2}\right)$, 2.20-2.16 (m, 2H, $\left.\mathrm{CH}_{2}\right), 2.02-1.96\left(\mathrm{~m}, 4 \mathrm{H}, \mathrm{CH}_{2}\right), 1.12-1.08\left(\mathrm{~m}, 6 \mathrm{H}, \mathrm{CH}_{3}\right), 1.06-0.93\left(\mathrm{~m}, 6 \mathrm{H}, \mathrm{CH}_{3}\right) \mathrm{ppm}$. ${ }^{13} \mathrm{C}\left\{{ }^{1} \mathrm{H}\right\}$ NMR $\left(75 \mathrm{MHz}, \mathrm{CDCl}_{3}\right): \delta=164.2(\mathrm{~s}, \mathrm{C}=\mathrm{O}), 161.2$ and $122.7\left(\mathrm{~s}, \mathrm{C}_{\text {arom }}\right), 151.1$ and $149.5(\mathrm{~s},=\mathrm{C})$, 132.1 and $115.2\left(\mathrm{~s}, \mathrm{CH}_{\text {arom }}\right), 117.5$ and $117.0(\mathrm{~s},=\mathrm{CH}), 26.6,25.6,18.8$, and $18.6\left(\mathrm{~s}, \mathrm{CH}_{2}\right), 13.9,13.8$, 11.4, and $11.3\left(\mathrm{~s}, \mathrm{CH}_{3}\right)$ ppm. IR (neat): $v=2968(\mathrm{~m}), 2912(\mathrm{~m}), 2875(\mathrm{~m}), 1729(\mathrm{~s}), 1691(\mathrm{~m}), 1604(\mathrm{~s})$, $1504(\mathrm{~s}), 1462(\mathrm{~m}), 1418(\mathrm{w}), 1376(\mathrm{w}), 1263$ (s), 1237 (s), $1181(\mathrm{~m}), 1086(\mathrm{~s}), 1022(\mathrm{w}), 972(\mathrm{w}), 850(\mathrm{~m})$, $746(\mathrm{~m}) \mathrm{cm}^{-1}$. HRMS (ESI): $\mathrm{m} / z$ 325.1763, $\left[\mathrm{M}+\mathrm{Na}^{+}\right]$(calcd. for $\left.\mathrm{C}_{19} \mathrm{H}_{26} \mathrm{O}_{3} \mathrm{Na}: 325.1774\right)$.

\subsection{X-ray Crystal Structure Determination of Compound $2 a$}

Crystals suitable for X-ray diffraction analysis were obtained by slow diffusion of hexane into a saturated solution of compound $\mathbf{2 a}$ in dichloromethane. The most relevant crystal and refinement data are collected in Table 2. Diffraction data were recorded on an Oxford Diffraction Xcalibur Nova single-crystal diffractometer, using Cu-K $\alpha$ radiation $(\lambda=1.5418 \AA)$, with a crystal-to-detector distance fixed at $62 \mathrm{~mm}$ and using the oscillation method, with $1^{\circ}$ oscillation and variable exposure time per frame of 2.5-6.5 s. The data collection strategy was calculated with the program CrysAlis Pro CCD [40]. Data reduction and cell refinement were performed with the program CrysAlis Pro RED [40]. Empirical absorption correction was applied by means of a SCALE3 ABSPACK algorithm as implemented in the program CrysAlis Pro RED [40]. The software package WINGX was used for space group 
determination, structure solution, and refinement [41]. The structure was solved by direct methods using SHELXL97 [42]. Isotropic least-squares refinement on $F^{2}$ using SHELXL97 was performed [42]. During the final stages of the refinement, all the positional parameters and the anisotropic temperature factors of all the non- $\mathrm{H}$ atoms were refined. The coordinates of the $\mathrm{H}$ atoms were found from different Fourier maps and included in the refinement with isotropic parameters. The function minimized was $\left[\Sigma w\left(F_{\mathrm{o}}{ }^{2}\right.\right.$ $\left.\left.-F_{\mathrm{C}}{ }^{2}\right) / \Sigma w\left(F_{\mathrm{o}}{ }^{2}\right)\right]^{1 / 3}$ where $w=1 /\left[\sigma^{2}\left(F_{\mathrm{o}}{ }^{2}\right)+(0.0457 P)^{2}+0.2366 P\right]$ with $\sigma\left(F_{\mathrm{o}}{ }^{2}\right)$ from counting statistics and $P=\left(\operatorname{Max}\left(F_{\mathrm{o}}{ }^{2}, 0\right)+2 F_{c}{ }^{2}\right) / 3$. Atomic scattering factors were taken from the International Tables for $\mathrm{X}$-ray Crystallography [43]. Geometrical calculations were made with PARST [44]. The crystallographic plots were made with DIAMOND [45]. Supplementary crystallographic data for the structural analysis have been deposited with the Cambridge Crystallographic Data Centre, CCDC-1961685.

Table 2. Crystal data and structure refinement details for compound 2a.

\begin{tabular}{|c|c|}
\hline Chemical Formula & $\mathrm{C}_{25} \mathrm{H}_{25} \mathrm{O}_{3} \mathrm{AuClFePS}$ \\
\hline fw & 724.74 \\
\hline $\mathrm{T}(\mathrm{K})$ & 130(1) \\
\hline cryst. syst. & monoclinic \\
\hline space group & $\mathrm{P} 21 / \mathrm{n}$ \\
\hline cryst. size $\mathrm{mm}^{3}$ & $0.24 \times 0.10 \times 0.07$ \\
\hline$a, \AA$ & $10.15090(10)$ \\
\hline$b, \AA$ & $14.6795(2)$ \\
\hline$c, \AA$ & $16.9056(2)$ \\
\hline$\alpha, \operatorname{deg}$ & 90 \\
\hline$\beta, \operatorname{deg}$ & $101.7130(10)$ \\
\hline$\gamma, \operatorname{deg}$ & 90 \\
\hline Z & 4 \\
\hline$V, \AA^{3}$ & $2466.65(5)$ \\
\hline$\rho_{\text {calcd }}, \mathrm{g} \mathrm{cm}^{-3}$ & 1.952 \\
\hline$\mu, \mathrm{mm}^{-1}$ & 18.351 \\
\hline $\mathrm{F}(000)$ & 1408 \\
\hline$\theta$ range, deg & 3.0104 to 69.6789 \\
\hline index ranges & $-10 \leq \mathrm{h} \leq 12 ;-16 \leq \mathrm{k} \leq 17 ;-20 \leq 1 \leq 18$ \\
\hline completeness to $\theta_{\max }$ & $98 \%$ \\
\hline no. of data collected & 12340 \\
\hline no. of unique data & 4556 \\
\hline no. of parameters/restrains & $332 / 0$ \\
\hline refinement method & full-matrix least-squares on $\mathrm{F}^{2}$ \\
\hline goodness of fit on $\mathrm{F}^{2}$ & 1.082 \\
\hline $\mathrm{R} 1^{a}[\mathrm{I}>2 \sigma(\mathrm{I})]$ & 0.0271 \\
\hline $\mathrm{wR} 2^{a}[\mathrm{I}>2 \sigma(\mathrm{I})]$ & 0.0723 \\
\hline R1 (all data) & 0.0292 \\
\hline wR2 (all data) & 0.0741 \\
\hline
\end{tabular}

${ }^{a} \mathrm{R} 1=\sum\left(\left|F_{\mathrm{o}}\right|-\left|F_{\mathrm{c}}\right|\right) / \sum\left|F_{\mathrm{o}}\right| ; \mathrm{wR} 2=\left\{\sum\left[\mathrm{w}\left({F_{\mathrm{o}}}^{2}-{F_{\mathrm{c}}}^{2}\right) \sum\right] / \sum\left[\mathrm{w}\left(F_{\mathrm{o}}{ }^{2}\right)^{2}\right]\right\}^{\frac{1}{2}}$.

\section{Conclusions}

In summary, new gold(I) complexes featuring hydrophilic ferrocenylphophino sulfonate ligands were synthesized, i.e., compounds $\left[\mathrm{AuCl}\left\{\left(\eta^{5}-\mathrm{C}_{5} \mathrm{H}_{3} \mathrm{PR}_{2}\left(\mathrm{SO}_{3}{ }^{\mathrm{i}} \mathrm{Pr}\right)\right) \mathrm{Fe}\left(\eta^{5}-\mathrm{C}_{5} \mathrm{H}_{5}\right)\right\}\right](\mathrm{R}=\mathrm{Ph}(\mathbf{2 a}), p$ - Tol (2b), $\mathrm{Cy}(\mathbf{2 c})$ ), and evaluated as potential catalysts for hydro-oxycarbonylation reactions of nonactivated internal alkynes in water. In combination with AgOAc, all of them became active, delivering the corresponding enol ester products with complete Z-selectivity. Employing 2a/AgOAc, whose activity was found to be superior to that of the previously reported $\left[\mathrm{AuCl}\left(\mathrm{PPh}_{3}\right)\right] / \mathrm{AgOAc}$ system, the scope of the process could also be demonstrated. The work presented herein provides additional evidence of the utility of ferrocenylphophino sulfonates $\left(\eta^{5}-\mathrm{C}_{5} \mathrm{H}_{3} \mathrm{PR}_{2}\left(\mathrm{SO}_{3}{ }^{\mathrm{i}} \mathrm{Pr}\right)\right) \mathrm{Fe}\left(\eta^{5}-\mathrm{C}_{5} \mathrm{H}_{5}\right)(\mathbf{1 a}-\mathbf{c})$ as auxiliary ligands for metal-catalyzed organic reactions in environmentally friendly aqueous media. 
Supplementary Materials: The following are available online at http://www.mdpi.com/2073-4344/9/11/955/s1, Figures S1-S9: NMR spectra of the gold(I) complexes 2a-c, and Figures S10-S44: NMR spectra of the enol esters 5aa-ea.

Author Contributions: Conceptualization, V.C. and D.S.; Synthesis of ligands, K.A. and J.G.; Synthesis of complexes and catalytic experiments, J.F. and M.E.M.-N.; X-ray diffraction, J.F.; All the authors contributed to the discussion of the experimental results as well as writing and editing of the manuscript.

Funding: This research was funded by the Spanish Ministry of Economy, Industry, and Competitiveness (MINECO project CTQ2016-75986-P) and the University of Oviedo (project PAPI-18-GR-2011-0032).

Acknowledgments: M.E.M.-N. thanks the National Autonomous University of México (UNAM) and CONACyT (scholarship 620618) for a mobility grant to make a short stay at the University of Oviedo. K.A. thanks the CONICYT-PFCHA (scholarship 2018-21181046) and PIIC program of the USM.

Conflicts of Interest: The authors declare no conflicts of interest.

\section{References}

1. Gooßen, L.J.; Paetzold, J. Decarbonylative Heck olefination of enol esters: Salt-free and environmentally friendly access to vinyl arenes. Angew. Chem. Int. Ed. 2004, 43, 1095-1098.

2. Geibel, I.; Dierks, A.; Schmidtmann, M.; Christoffers, J. Formation of $\delta$-lactones by cerium catalyzed, Baeyer-Villiger-type coupling of $\beta$-oxoesters, enol acetates, and dioxygen. J. Org. Chem. 2016, 81, 7790-7798. [CrossRef] [PubMed]

3. Geibel, I.; Christoffers, J. Synthesis of 1,4-diketones from $\beta$-oxo esters and enol acetates by cerium-catalyzed oxidative umpolung reaction. Eur. J. Org. Chem. 2016, 2016, 918-920. [CrossRef]

4. Kleman, P.; González-Liste, P.J.; García-Garrido, S.E.; Cadierno, V.; Pizzano, A. Highly enentioselective hydrogenation of 1-alkylvinyl benzoates: A simple, nonenzymatic access to chiral 2-alkanols. Chem. A Eur. J. 2013, 19, 16209-16212. [CrossRef] [PubMed]

5. León, F.; González-Liste, P.J.; García-Garrido, S.E.; Arribas, I.; Rubio, M.; Cadierno, V.; Pizzano, A. Broad scope synthesis of ester precursors of nonfunctionalized chiral alcohols based on the asymmetric hydrogenation of $\alpha, \beta$-dialky, $\alpha, \beta$-diaryl, and $\alpha$-alkyl- $\beta$-aryl-vinyl esters. J. Org. Chem. 2017, 82, 5852-5867. [CrossRef]

6. Jia, J.; Fan, D.; Zhang, J.; Zhang, Z.; Zhang, W. An atropos biphenyl bisphosphine ligand with 2,2'-tert-butylmethylphosphino groups for the rhodium-catalyzed asymmetric hydrogenation of enol esters. Adv. Synth. Catal. 2018, 360, 3793-3800. [CrossRef]

7. Corey, E.J.; Ghosh, A.K. Manganese (III)-promoted annulation of enol ethers and esters to fused spiro 2-cyclopentenones. Tetrahedron Lett. 1987, 28, 175-178. [CrossRef]

8. Panda, N.; Mothkuri, R.; Pal, A.; Paital, A.R. Copper-catalyzed synthesis of $\alpha$-naphthols from enol esters. Adv. Synth. Catal. 2013, 355, 2809-2814. [CrossRef]

9. Panda, N.; Mishra, P.; Mattan, I. Synthesis of isocoumarins via silver (I)-mediated annulation of enol esters. J. Org. Chem. 2016, 81, 1047-1056. [CrossRef]

10. Jena, R.K.; Das, U.K.; Ghorai, A.; Bhattacharjee, M. Ruthenium-catalyzed addition of carboxylic acids to propargylic alcohols: An easy route to $O$-dienyl esters and their tandem atom-transfer radical polymerization. Eur. J. Org. Chem. 2016, 36, 6015-6021. [CrossRef]

11. Foarta, F; Landis, C.R. Condensation oligomers with sequence control but without coupling reagents and protecting groups via asymmetric hydroformylation and hydroacyloxylation. J. Org. Chem. 2016, 81, 11250-11255. [CrossRef] [PubMed]

12. Hwang, J.; Lee, H.-C.; Antonietti, M.; Schmidt, B.V.K.J. Free radical and RAFT polymerization of vinyl esters in metal-organic frameworks. Polym. Chem. 2017, 8, 6204-6208. [CrossRef]

13. Alonso, F.; Beletskaya, I.; Yus, M. Transition-metal-catalyzed addition of heteroatom-hydrogen bonds to alkynes. Chem. Rev. 2004, 104, 3079-3160. [CrossRef] [PubMed]

14. Beller, M.; Seayad, J.; Tillack, A.; Jiao, H. Catalytic Markovnikov and anti-Markovnikov functionalization of alkenes and alkynes: Recent developments and trends. Angew. Chem. Int. Ed. 2004, 43, 3368-3398. [CrossRef]

15. Hintermann, L. Recent developments in metal-catalyzed additions of oxygen nucleophiles to alkenes and alkynes. Top. Organomet. Chem. 2010, 31, 123-155.

16. Patil, N.T.; Kavthe, R.D.; Shinde, V.S. Transition metal-catalyzed addition of C-, N- and O-nucleophiles to unactivated C-C multiple bonds. Tetrahedron 2012, 68, 8079-8146. [CrossRef] 
17. Bruneau, C. Group 8 metals-catalyzed O-H bond addition to unsaturated molecules. Top. Organomet. Chem. 2013, 43, 203-230.

18. González-Liste, P.J.; Francos, J.; García-Garrido, S.E.; Cadierno, V. The intermolecular hydro-oxycarbonylation of internal alkynes: Current state of the art. Arkivoc 2018, ii, 17-39. [CrossRef]

19. Kawatsura, M.; Namioka, J.; Kajita, K.; Yamamoto, M.; Tsuji, H.; Itoh, T. Ruthenium-catalyzed regio- and stereoselective addition of carboxylic acids to aryl and trifluoromethyl group substituted unsymmetrical internal alkynes. Org. Lett. 2011, 13, 3285-3287. [CrossRef]

20. Lu, X.; Zhu, G.; Ma, S. A novel regio- and stereo-specific hydroacetoxylation reaction of 2-alkynoic acid derivatives. Tetrahedron Lett. 1992, 33, 7205-7206. [CrossRef]

21. Yin, J.; Bai, Y.; Mao, M.; Zhu, G. Silver-catalyzed regio- and stereoselective addition of carboxylic acids to ynol ethers. J. Org. Chem. 2014, 79, 9179-9185. [CrossRef] [PubMed]

22. Smith, D.L.; Goundry, W.R.F.; Lam, H.W. Palladium-catalyzed hydroacyloxylation of ynamides. Chem. Commun. 2012, 48, 1505-1507. [CrossRef] [PubMed]

23. González-Liste, P.J.; Francos, J.; García-Garrido, S.E.; Cadierno, V. Gold-catalyzed regio- and stereoselective addition of carboxylic acids to iodoalkynes: Access to (Z)- $\beta$-iodoenol esters and 1,4-disubstituted (Z)-enynyl esters. J. Org. Chem. 2017, 82, 1507-1516. [CrossRef] [PubMed]

24. Chary, B.C.; Kim, S. Gold (I)-catalyzed addition of carboxylic acids to alkynes. J. Org. Chem. 2010, 75, 7928-7931. [CrossRef] [PubMed]

25. Wang, Y.; Wang, Z.; Li, Y.; Wu, G.; Cao, Z.; Zhang, L. A general ligand design for gold catalysis allowing ligand-directed anti-nucleophilic attack of alkynes. Nat. Commun. 2014, 5, 3470. [CrossRef]

26. Dupuy, S.; Gasperini, D.; Nolan, S.P. Highly efficient gold (I)-catalyzed regio- and stereoselective hydrocarboxylation of internal alkynes. ACS Catal. 2015, 5, 6918-6921. [CrossRef]

27. Chen, J.-F.; Li, C. Enol ester synthesis via cobalt-catalyzed regio- and stereoselective addition of carboxylic acids to alkynes. Org. Lett. 2018, 20, 6719-6724. [CrossRef]

28. Dixneuf, P.H.; Cadierno, V. (Eds.) Metal-Catalyzed Reactions in Water; Wiley-VCH: Weinheim, Germany, 2013.

29. Francos, J.; Cadierno, V. Metal-catalyzed intra- and intermolecular addition of carboxylic acids to alkynes in aqueous media: A review. Catalysts 2017, 7, 328. [CrossRef]

30. González-Liste, P.J.; García-Garrido, S.E.; Cadierno, V. Gold (I)-catalyzed addition of carboxylic acids to internal alkynes in aqueous medium. Org. Biomol. Chem. 2017, 15, 1670-1679. [CrossRef]

31. Gorin, D.J.; Sherry, B.D.; Toste, F.D. Ligands effects in homogeneous Au catalysis. Chem. Rev. 2008, 108, 3351-3378. [CrossRef]

32. Sierra, D.; Contreras, C.; Francos, J.; Gómez, J.; Cadierno, V. Novel ferrocenylphosphino sulfonates: Synthesis, crystal structure and preliminary application as ligands in aqueous catalysis. J. Organomet. Chem. 2018, 854, 106-112. [CrossRef]

33. Canales, F.; Gimeno, M.C.; Jones, P.G.; Laguna, A.; Sarroca, C. Substitution reaction studies on [ $\mathrm{Au}_{2} \mathrm{Cl}_{2}(\mu$-dppf)] (dppf = 1,1'-bis(diphenylphosphino)ferrocene). Synthesis of the first gold (I) complex with a $\mu_{3}$-2-pyridinethiolate ligand. Inorg. Chem. 1997, 36, 5206-5211. [CrossRef]

34. Rampazzi, V.; Roger, J.; Amardeil, R.; Penouilh, M.-J.; Richard, P.; Fleurat-Lessard, P.; Hierson, J.-C. Gold (I) complexes of ferrocenyl polyphosphines: Aurophilic gold chloride formation and phosphine-concerted

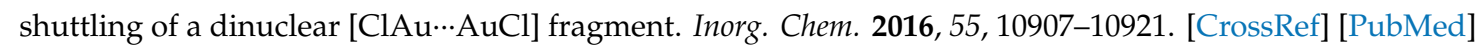

35. Delpont, N.; Escofet, I.; Pérez-Galán, P.; Spiegl, D.; Raducan, M.; Bour, C.; Sinisi, R.; Echavarren, A. Modular chiral gold (I) phosphite complexes. Catal. Sci. Technol. 2013, 3, 3007-3012. [CrossRef]

36. Goodwin, J.A.; Aponick, A. Regioselectivity in the Au-catalyzed hydration and hydroalkoxylation of alkynes. Chem. Commun. 2015, 51, 8730-8741. [CrossRef]

37. Armarego, W.L.F.; Chai, C.L.L. Purification of Laboratory Chemicals, 5th ed.; Butterworth-Heinemann: Oxford, UK, 2003.

38. Brandys, M.-C.; Jennings, M.C.; Puddephatt, R.J. Luminescent gold (I) macrocycles with diphosphine and 4, 4'-bipyridyl ligands. J. Chem. Soc. Dalton Trans. 2000, 4601-4606. [CrossRef]

39. Tsukada, N.; Takahashi, A.; Inoue, Y. Hydrocarboxylation of unactivated internal alkynes with carboxylic acids catalyzed by dinuclear palladium complexes. Tetrahedron Lett. 2011, 52, 248-250. [CrossRef]

40. CrysAlis ${ }^{\text {Pro }}$ CCD \& CrysAlis ${ }^{\text {Pro }}$ RED; Oxford Diffraction Ltd.: Oxford, UK, 2008.

41. Farrugia, L.J. WinGX and ORTEP for Windows: An update. J. Appl. Cryst. 2012, 45, 849-854. [CrossRef] 
42. Sheldrick, G.M. SHELXL97: Program for the Refinement of Crystal Structures; University of Göttingen: Göttingen, Germany, 1997.

43. Wilson, A.J.C. (Ed.) International Tables for X-ray Crystallography, Volume, C; Kluwer Academic Publishers: Dordrecht, The Netherlands, 1992.

44. Nardelli, M. PARST: A system of FORTRAN routines for calculating molecular structure parameters from results of crystal structure analyses. Comput. Chem. 1983, 7, 95-98. [CrossRef]

45. Brandenburg, K.; Putz, H. DIAMOND; Crystal Impact GbR: Bonn, Germany, 1999; Available online: http://www.crystalimpact.com/diamond (accessed on 1 September 2019).

(C) 2019 by the authors. Licensee MDPI, Basel, Switzerland. This article is an open access article distributed under the terms and conditions of the Creative Commons Attribution (CC BY) license (http://creativecommons.org/licenses/by/4.0/). 